\title{
Jurnal Ilmu Sosial dan Pendidikan (JISIP)
}

\author{
Vol. 5 No. 3 Juli 2021
}

Terakreditasi Peringkat 5 (No. SK: 85/M/KPT/2020)

e-ISSN : 2656-6753, p-ISSN: 2598-9944

DOI: 10.36312/jisip.v5i3.2169/http://ejournal.mandalanursa.org/index.php/JISIP/index

\section{Kegiatan Pembelajaran Kreatif Guru Di Masa Pandemi Covid 19 Untuk Meningkatkan Minat Belajar Siswa Pada Mi Ma'arif NU Rabak}

\author{
${ }^{1}$ Umi Hidayatun, ${ }^{2}$ Abdul Wachid B.S. \\ ${ }^{1}$ Pascasarjana IAIN Purwokerto \\ ${ }^{2}$ Dosen IAIN Purwokerto \\ Jalan Ahmad Yani No.40A Purwokerto \\ e-mail:201763019@mhs.iainpurwokerto.ac.id, filsafat.pasca.awbs@gmail.com
}

\begin{tabular}{l}
\hline Article Info \\
\hline Article history: \\
Article Received: July 012021 \\
Publised: July 102021
\end{tabular}

\section{Keywords: \\ Pembelajaran Kreatif, Minat Belajar Siswa, MI Ma'arif NU Rabak.}

\begin{abstract}
This study aims to determine: (1) the rules for the enforcement of corruption in Indonesia, (2) the influence of the culture of rules on the enforcement of the rules for corruption in Indonesia, (3) the efforts of educational forums to eradicate corruption in Indonesia. The procedure for collecting and collecting data used in this research is through a literature study/documentary study, using relevant regulatory materials, collecting materials that will be used in this research, conducting searches to find relevant regulatory materials. using Legal Culture and Criminal Acts of Corruption in efforts to overcome Corruption Crimes in global education in Indonesia. Through this data collection technique, it is necessary to find a concept that can answer the news of the rules in this study. Based on the output of this study, it appears that the eradication of corruption by the government has not resulted in the required output. The complexity of the fight against corruption in Indonesia is apparently not relatively solved by relying on preventive and investigative tactics, but also educative tactics.
\end{abstract}

\author{
Article Info \\ Article history: \\ Artikel diterima : Juli 012021 \\ Publikasi : Juli 102021
}

Keywords:
Creative Learning, Student
Interest, MI Ma'arif NU Rabak.

\begin{abstract}
Abstrak
The research was conducted with the aim of describing the creative learning activities of teachers during the COVID-19 pandemic at MI Ma'arif NU Rabak. This research uses descriptive qualitative method. The analysis technique used is data reduction technique, data presentation and conclusion. The result of the research is that teachers' creative learning activities during the pandemic can increase children's interest in learning. Teachers can create creative learning using online learning. This learning can attract students' interest in learning, so students do not feel bored. With teacher guidance in online learning, of course, it can foster student learning enthusiasm. Using continuous greetings through class groups, the teacher seems to be in front of students in teaching and learning activities, therefore students feel happy and as an increase in student learning enthusiasm.

This is an open access article under the Lisensi Creative Commons AtribusiBerbagiSerupa 4.0 Internasional
\end{abstract}

\section{Corresponding Author \\ Umi Hidayatun \\ Pascasarjana IAIN Purwokerto \\ Email:201763019@mhs.iainpurwokerto.ac.id}

\section{PENDAHULUAN}

Pada era sekarang, menuntut guru untuk menciptakan aktivitas proses belajar mengajar kreatif sehingga dapat meningkatkan minat belajar siswa. Berkaitan dengan kasus pandemic covid-19 yang setiap harinya selalu meningkat menyebabkan berhentinya pembelajaran tatap 
muka tidak diperbolehkan. Sehingga pembelajaran dilakukan secara during atau pembelajaran jarak jauh (PJJ). Banyak kegiatan pelatihan-pelatihan guru secara berkala berkaitan dengan PJJ. Guru harus selalu siap sedia untuk dapat melakukan dan mengikuti kegiatan pelatihan PJJ. Guru dituntut untuk dapat menunjukkan keterampilannya dalam melakukan kegiatan pembelajaran di masa pandemi tersebut, dikarenakan hal tersebut merupakan sebuah tantangan terkait perkembangan teknologi agar tidak tertinggal dengan sekolah-sekolah lain.

Awalnya sekolah sudah mempersiapkan semua perangkat pembelajaran dan protokol kesehatan dikarenakan ada peraturan yang menyebutkan bahwa Bulan September 2020 akan dilakukan pembelajaran secara tatap muka di sekolah. Namun tidak jadi dilaksanakan dikarenakan kasus Covid-19 tiap harinya selalu meningkat, sehingga pihak sekolahpun mengikuti kebijakan tersebut. Dengan demikian, pendidik harus tetap menyiapkan teknik pembelajaran yang menarik bagi siswa.

Berkaitan munculnya wabah virus Corona di berbagai belahan dunia, maka sistem pendidikan khususnya di Indonesia harus mulai mencari suatu inovasi untuk kegaiatan pembelajaran. Terlebih beredarnya surat No.4 Tahun 2020 dari Menteri Pendidikan dan Kebudayaan yang menganjurkan seluruh kegiatan di lembaga pendidikan harus selalu jaga jarak dan seluruh penyampaian materi akan disampaikan dirumah masing-masing.

Semenjak bulan Maret 2020, pembelajaran dilakukan dirumah (BDR). Sehingga guru sebagai pendidik harus tetap memastikan kegiatan pembelajaran harus tetap berlangsung walaupun siswa berada di rumah. Inovasi pembelajaran dengan memanfaatkan dan memaksimalkan media seperti media online sebagai pembelajaran daring harus dilakukan oleh guru.

Guru harus selalu dituntuk untuk dapat melakukan pembelajaran secara $e$-learning sebagai pemanfaatan IPTEK. Sistem pembelajaran dilakukan melalui perangkat computer atau smartphone yang terkoneksi internet. Pembelajaran dilakukan melalui whatsaap, telegram, aplikasi zoom, atau media sosial lainnya. Supaya pembelajaran tidak terkesan monoton dan siswa merasa bosan dan stres, maka guru harus mendesain tugas- tugas untuk dikerjakan dalam bentuk proyek atau dengan melibatkan siswa dalam pemanfaatan aplikasi pembelajaran yang inovatif, dan kreatif, oleh karena itu pembelajaran dapat tersampaikan maksimal.

Menurut Syawal Gultom (2020), guru sebagai pemeran utama dalam pembentukan siswa pada masa pandemi. Oleh karena itu, guru harus mampu membuat metode pembelajaran kreatif bagi siswa agar pembelajaran dapat berjalan walaupun hanya dilakukan di rumah. Terdapat beberapa pemahaman terkait pandemic supaya pembelajaran tetap dapat berlangsung, diantaranya:

1. Pembuktian runtuhnya ke-akuan dan kuatnya ke-kitaan.

2. Pembangunan prinsip mutuality yaitu dengan melakukan pemberian, penerimaan, dan penghargaan.

3. Perubahan mindset metodologi dan sikap hidup bersih dengan rajin melakukan cuci tangan

4. Memaksa guru untuk dapat berkreasi supaya menarik minat belajar siswa.

Wabah Covid menuntut untuk kita harus selalu memanfaatkan teknologi supaya pembelajaran tetap berlangsung. Kreativitas guru dalam melakukan aktivitas pembelajaran daring berpengaruh terhadap atensi siswa. Baik pendidik maupun orang tua harus selalu menjalin komunikasi untuk memantau proses belajar siswa agar pembelajaran dapat diterima siswa secara optimal.

Menurut Zuharini dkdk (2009), pendidikan sebagai upaya pengalihan (pelimpahan) pengetahuan, pengalaman, kecakapan, serta keahlian dari generasi tua ke generasi muda untuk mempersiapkan pemenuhan kehidupan yang layak. Selain itu, pendidikan juga merupakan suatu upaya dalam melakukan pembimbingan terhadap siswa menuju tahap kedewasaan agar dapat bertanggung jawab atas perbuatan dan tingkah lakunya sendiri. Penyampaian dalam kegiatan pembelajaran merupakan sebuah tujuan pengajaran atau tujuan instruksional (Sardiman, 2011). Tujuan pengajaran sebagai hasil dari proses pembelajaran yang dilakukan oleh siswa dalam keadaan pembelajaran yang kondusif. 
Menurut Dian (2020), budaya digital sebagai bagian penting dalam kehidupan pada era sekarang. Guru dituntuk agar selalu keratif dalam penggunaan teknologi pada kegiatan di kelas. Pemanfaatan teknologi dapat meningkatkan minat belajar anak. Namun, terdapat kendala dalam pemanfaat teknologi di Indonesia menjadi kecemasan tersendiri apalagi jika disalahgunakan oleh pihak-pihak tertentu.

Menurut Nur (2011), masa pandemic saat ini membutuhkan adanya tenaga pendidik yang berperan penting dalam kegiatan belajar mengajar meskipun pembelajaran dilakukan di rumah. Dilakukan beberapa pembaharuan terkait masa pandemic seperti ini diantaranya pembaharuan kurikulum dan metode-metode pembelajaran. Guru sebagai tenaga yang bertugas dalam pembuatan dan pelaksanaan kegiatan belajar mengajar, serta sebagai penilai dan pembimbing siswa dalam mewujudkan cita-citanya.

Menurut Syaharuddin \& Mutiani, peranan guru dalam penyelenggaraan kurikulum pembelajaran itu sangat penting. Kurikulum disusun sebagai panduan penentuan mata pelajaran pada tiap tingkat pendidikan. Menurut UU NO. 20 Tahun 2003 Pasal 1 Ayat 19,kurikulum bukan hanya berkaitan dengan mata pelajaran saja, akan tetapi berkaitan dengan rencana, tujuan, isi, dan bahan ajar, serta tata cara pengajaran yang dijadikan sebagai panduan dalam penyelenggaraan kegiatan belajar mengajar dalam pencapaian tujuan pendidikan.

Berdasarkan uraian di atas, dengan kegiatan pembelajaran kreatif guru di masa pandemic covid-19 untuk meningkatkan diharapkan meningkatkan belajar anak. Akan tetapi kenyataannya pembelajaran kreatif yang dilakukan guru untuk meningkatkan belajar anak masih jauh dari harapan ,karena keterbatasan kemampuan guru dalam menguasai tekhnologi. Dari 25 anak dikelas 3 kebanyakan mereka memiliki HP untuk mengikuti pembelajaran during, akan tetapi dari jumlah anak yang ada di kelas 3 hanya 10 anak yang mengerjakan tugas dari guru.

\subsection{Rumusan Masalah}

Berdasarkan laatar belakang masalah, rumusan masalah dalam penelitian ini yaitu bagaimana kreatif guru dalm pembelajaran di masa covid- 19 untuk meningkatkan meningkatkan minat belajar anak pada MI Ma'arif NU Rabak.

\section{METODE PENELITIAN}

Jenis penelitian ini merupakan jenis penelitian deskriptif yaitu dengan mendeskripsikan gambaran dan penjelasan terkait data-data yang diperoleh dalam penelitian. Tujuan dari metode deskripsi yaitu sebagai pemberian gambaran serta penajabaran terkait kejadian yang diteliti. Sehingga metode deskriptif diharapkan dapat meneliti kondisi terkait dengan perhatian orangtua pada anak saat pembelajaran jarak jauh dalam masa pandemi ini. Penggunaan metode deskripsi tersebut dapat mendeskripsikan secara jelas hasil keadaan yang terjadi.

Penulis menggunakan pendekatan kualitatif, sebagai upaya untuk melakukan tindakan kepada subjek penelitian dalam upaya meningkatkan perhatian orangtua pada anak dalam pembelajaran jarak jauh. Menurut Wiratna, penelitian kualitatif merupakan jenis penelitian yang hasilnya dapat berupa data deskriptif terakit pembicaraan, penulisan, dan tingkah laku subjek yang diteliti. Dalam kegiatan wawancara penulis melakukan wawancara terhadap delapan guru di madrasah diantaranya Bapak Moh.Amirudin,S.Pd, Bapak Shofiyulloh,S.Pd.O.R, Ibu Siti Khakimah,S.Pd.I, Ibu Siti Fatimah,S.Pd.I, Ibu Ipah Nurhayati,S.Pd.I, Ibu Indri Setiyani,S.Pd.I, Ibu IKa Widiya Astuti,S.Pd.I, dan Ibu Nisa Aulia Rahma). Hasil dari observasi atau wawancara akan lebih terpecaya apabila didukung dengan dokumentasi (Djama'an \& Aan, 2014). Penggunaan teknik dokumentasi bertujuan dalam pelengkapan hasil observasi dan wawancara. Dokumentasi berkaitan dengan catatan-catatan dan data-data tentang pembelajaran kreatif yang dilakukan guru untuk meningkatkan minat belajar anak. Sehingga untuk studi kasus, penggunaan dokumen yang peneliti lakukan sebagai pendukunhh dan penambah bukti dari sumber-sumber lain. Selain wawancara dan observasi peneliti menggunakan beberapa sumber rujukan buku tugas anak, lembar kegiatan sehari-hari anak, dan foto-foto atau kegiatan program mengenai proses pembelajaran jarak jauh. 
Analisis data merupakan proses dalam pencarian dan penyusunan data hasil penelitian dengan pengorganisasian data dan pemilihan data serta pemahaman dalam pembuatan kesimpulan agar dapat tercena dengan jelas. Teknik analisis data yang digunakan yaitu teknik analisis kualitatif menurut Miles dan Hubberman (Sugiyono, 2017) yaitu pengumpulan data, reduksi data, penyajian data dan langkah terakhir adalah penarikan kesimpulan.

1. Reduksi data merupakan penyederhanaan melalui proses seleksi, pemfokusan dan keabsahan data mentah menjadi informasi yang bermakna, sehingga memudahkan penarikan kesimpulan.

2. Penyajian data dalam bentuk naratif. Penyajian-penyajian data berupa sekumpulan informasi yang tersusun secara sistematis dan mudah dipahami.

3. Penarikan kesimpulan merupakan tahap akhir dalam analisis data yang dilakukan melihat hasil reduksi data tetap mengaju pada rumusan masalah secara tujuan yang hendak dicapai. Data yang telah disusun dibandingkan antara satu dengan yang lain untuk ditarik kesimpulan sebagai jawaban dari permasalahan yang ada. Agar data menjadi valid, oleh karena itu harus mencatat point yang ada di lapangan, pengumpulan data, serta memperhatikan proses di lapangan supaya hasilnya lebih maksimal.

\section{HASIL DAN PEMBAHASAN}

Hasil penelitian kegiatan pembelajaran kreatif guru di masa pandemi covid 19 untuk meningkatkan akan dijelaskan sebagai berikut,pembelajaran kreatif guru sanAgat di perlukan untuk meningkatkan belajar anak. Dengan model pembelajaran yang dilakukan oleh guru sangat di perlukan, apalagi dengan melihat pandemic saat ini belum juga berakhir. Dan guru mampu membuat gebrakan dengan pembelajaran yang kreatif sehingga anak akan selalu termotivasi dalam belajarnya.

Kegiatan pembelajaran secara daring dapat dilakukan melalui media whatsaap group, yaitu dengan guru membuat group di aplikasi whatsaap dengan mengundang semua anggota kelas untuk masuk ke dalam group tersebut. Selanjutnya pengunggahan materi ajar atau tugas kuliah dapat dilakukan melalui aplikasi whatsaap group tersebut. Siswa dapat membaca materi serta tugas sekolah melalui smartphone siswa masing-masing. Selain itu, siswa juga dapat melakukan tanya jawab ke guru terkait materi yang belum paham melalui group whatsaap tersebut.

\subsection{Pembelajran Kreatif Guru di masa pandemi covid 19}

Pelaksanaan kegiatan pembelajaran jarak jauh (PJJ) dirasa sulit oleh guru dikarenakan keterbatasan waktu. Sehingga perlu dilakukan pembangunan kreativitas guru dengan inovasi pembelajaran sebagai usaha pelaksanaan pembelajaran, dengan demikian maka beban mengajar guru sesuai dengan ketentuan yang berlaku. Kurangnya komunikasi antara guru dengan orang tua menyebabkan kurang terpantaunya proses belajar siswa. Banyak orang tua yang kurang memantau anaknya dikarenakan sibuk urusan pekerjaan, atau sebagainya.

Terbatasnya kemampuan orang tua dalam pemahaman materi ajar serta memberi motivasi ke siswa menyebabkan sering terjadinya keributan antara orang tua dan siswa dirumah. Hal tersebutlah yang terkadang menyebabkan siswa males untuk belajar. Selain itu juga didukung dengan penugasan dari guru yang terlalu banyak menyebabkan siswa stres. Dengan demikian maka perlu adanya strategi pembelajaran secara daring yang inovatif dan efektif.

Guru kreatif adalah guru yang dalam melakukan kegiatan pembelajaran selalu memberikan motivasi ke siswa seperti, pemikiran, fakta, dan ide- ide serta kombinasi antar keduanya. Guru kreatif dapat melakukan aktivitas belajar mengajar dengan penggabungan materi ajar, strategi pembelajaan, penggunaan media, dan kejadian dalam kehidupan seharihari. Selain itu juga diperlukan adanya penyediaan ruang untuk siswa agar dalam melakukan kegiatan pembelajaran dapat dilakukan secara interaktif, menyenangkan, menantang, serta memotivasi siswa agar selalu aktif, kreatif, dan mandiri disesuaikan dengan minat, bakat, dan perkembangan fisik serta psikologis siswa (Peraturan Pemerintah Nomor 19 Tahun 2005 tentang Standar Nasional Pendidikan). 
Terdapat beberapa aktivitas pembelajaran dalam perwujudan pembelajaran kreatif guru diantaranya :

a. Pembelajaran menggunakan ceramah (virtual online)

Paradigma pembelajaran online sebagai perubahan mengajar yang orientasinya berpusat pada pendidik, akan tetapi lebih penting orientasinya berpusat pada siswa. Pada jaman digital pembelajaran dilakukan dengan memanfaatkan teknologi, apalagi didukung dengan kondisi pandemic seperti sekarang.

Langkah yang dilakukan peneliti dalam hal ini untuk memperoleh informasi yaitu dengan wawancara. Teknik wawancara dilakukan dengan memberikan pertanyaan berkaitan dengan kegiatan pembelajaran kreatif guru yang dilakukan di masa pandemic untuk meningkatkan belajar anak.

Adapun pembelajaran kreatif guru dengan ceramah atau virtual secara online.Guru pertama yang dilakukan membuat video pembelajaran yang disesuikan dengan materi,setelah video dibuat di share ke group kelas.Sebelumnya guru menyampaikan kepada anak-anak supaya melihat video yang share di group supaya memperhatikan isi yang di ucapkan guru serta memberi tugas dalam pencatatan hal-hal penting berkaitan dengan materi ajar.

Metode ceramah sebagai pemberian peneranagn secara lisan kepada siswa, yang nantinya siswa akan mencatat hal-hal yang penting saja. Kegiatan tersebut dapat terlaksana dalam waktu singkat. Pembelajaran ini dapat dilakukan secara online dengan membuat video .Penjelasan singkat yang bisa dibagikan lewat wasthaaps group.

b. Pembelajaran menggunakan Google Classroom

Pembelajaran online menggunakan e-learning dibutuhkan sistem manajemen pendidikan yang dapat memudahkan pendidik dan muridnya dalam forum diskusi dalam aplikasi sebagai tempat ganti ruang kelas. Fasilitas tersebut adalah google classroom. Penggunaan aplikasi ini dapat memberikan bahan ajar lewat pembagian video rekaman, bahan ajar dalam format power point, modul pembelajaran, LKS, serta sumber belajar.

c. Pembelajaran Kooperatif

Pembelajaran kooperatif merupakan pembelajaran yang berpusat pada siswa dalam pengembangan keterampilan berpikir siswa dalam penyelesaian masalah dalam menghadapi era 5.0 untuk persiapan siswa agar dapat menjadi SDM yang berkualitas serta dapat memajukan bangsa. Oleh karena itu, guru harus dapat mengubah cara mengajar dan penyampaian bahan ajar agar siswa dapat berbagai informasi dan dapat saling berdiskusi. Kerjasama team dapat mengembangkan tanggung jawab antar siswa.

d. Pembelajaran dengan Game Quizizz

Kegiatan pembelajaran dapat dilakukan dengan penyertaan game didalamnya agar terkesan tidak monoton. Menurut Hoby (1995), game sebagai aktivitas untuk menyenangkan diri sendiri. Dengan demikian, game merupakan alat yang digunakan untuk menarik minat belajar siswa dalam penyertaan kegiatan pembelajaran dikarenakan game dapat membuat siswa lebih fokus dalam belajar. Game juga membuat siswa menemukan suatu hal baru yaitu pengguanan bahasa asing yang tidak pernah ditemui dalam materi ajar.

e. Pembelajaran dengan Penciptaan Karya yang Bermakna

Pembelajaran online tidak sebatas pemberian materi pelajaran saja, akan tetapi guru juga harus mempersiapkan generasi penerus yang memiliki kualitas bagus. Pembekalan siswa tentang pendidikan dan keterampilan oleh guru yaitu pembekalan bukan tentang keterampilan bertahan hidup namun juga keterampilan berpikir kritis, konstruktif, inovatif dan berkarakter. Dengan demikian, menuntut guru untuk melakukan pendesainan dan perencanaan proses belajar mengajar bermakna supaya siswa dapat menghubungkan makna proses belajar dengan kehidupan serta permasalahan- permasalahan hidup. Contohnya pemberian bahan ajar terkait wabah virus corona, peristiwa alam, pemanfaatan SDA, kepedulian lingkungan dan pemberian pembelajaran berkarakter. Meskipun 
pembelajaran dilakukan secara online, akan tetapi guru juga mengajak siswa agar dapat disiplin, kerjasama, saling menghargai, punya sopan santun, jujur dan saling peduli dengan yang lainnya (Regina, 2017).

f. Penilaian Secara Online

Penilaian merupakan hal terpenting untuk guru dalam pengukuran dan pencapaian tujuan pembelajaran. Penilaian terhadap siswa dapat menggunakan google form dalam aplikasi google classroom. Penggunaan media tersebut efektif sebagai media penilaian dikarenakan hasilnya dapat terekap didalamnya. Guru dapat langsung tahu hasilnya sehingga guru mudah dalam melakukan pengkoreksian. Penilaian dapat bervariasi dari pilihan ganda, uraian, menjodohkan dan menulis karangan dapat dilakukan di google form. Data yang tersimpan tidak akan mengalami kehilangan dikarenakan sudah disimpan dalam satu tempat di google classroom.

\subsection{Tantangan Pendidikan di Masa pandemi Covid-19}

Virus Corona berdampak pada sector pendidikan. Sebagai upaya pencegahannya maka diterapkan kebijakan, diantaranya pemberlakuan physical distancing. Pemberlakuan Pembatasan Sosial Berskala Besar (PSBB) dilakukan Pemerintah Indonesia dengan pengharusan segala aktivitas pengerjaannya dari rumah. Mulai kegiatan kerja hingga kegiatan belajar mengajar dilaksanakan di rumah, bertujuan sebagai pengurangan interaksi antar manusia.

Berdasarkan kebijakan tersebut maka pembelajaran dilakukan secara daring. Pembelajaran daring sebagai pembelajaran yang dilakukan dengan pemanfaatan platform yang dapat membantu proses jalannya pembelajaran walaupun secara jarak jauh. Seiring berkembanykan IPTEK, maka pembelajaran daring dapat terlaksana dengan penggunaan berbagai platform seperti e-learning, google clasroom, serta lainnya.

Selain itu pembelajaran daring dapat dilakukan dengan bentuk video conference dengan penggunaan beberapa platform diantaranya aplikasi zoom, google meet, dan visco webex. Pemanfaatan aplikasi-aplikasi tersebut tidak jarang. Whatsapp Group menjadi alternatif dalam pelaksanaan pembelajaran daring.

\subsection{Upaya Guru Dalam Peningkatan Motivasi Belajar Siswa}

Penumbuhan motivasi belajar siswa sebagai cara pengembangan kemampuan dan kemauan belajar. Caranya yaitu dengan momotivasi siswa terkait dengan pengalaman belajar.

Guru sebagai pendidik yang tugasnya memberikan pelajaran ke siswa dengan berupaya melakukan peningkatan motivasi belajar bagi siswa yang dirasa sulit dalam menerima pelajaran dari guru dengan cara :

1) Menjelaskan tujuan pembelajaran yang hendak tercapai,

2) Pembangkitan motivasi minat belajar siswa

3) Menciptakan kondisi belajar yang dirasa siswa menjadi nyaman dan senang,

4) Penggunaan model dan metode pembelajaran yang menarik dan bervariasi,

5) Pemberian pujian untuk keberhasilan siswa

6) Pemberian nilai untuk siswa

7) Pemberian komentar untuk setiap hasil tugas siswa

8) Menciptakan kerjasama dan persaingan yang sehat.

Usaha dalam kegiatan pembelajaran kreatif guru sangatlah penting dan diharapkan dapat meningkatkan pembelajaran anak di masa pandemic covid 19.Dengan pembelajaran during yang tentunya tidak membosankan anak didik,Guru memberikan materi lewat whastaap group kelas.Baik berupa video materi yang lansung disampaikan oleh guru,maupun berupa film yang sesuai dengan materi yang di share ke group.

Kegiatan yang peneliti lakukan untuk memperoleh informasi dalam penyelenggaraan penelitian adalah dengan wawancara. Wawancara dengan memberikan pertanyaan kepada informan mengenai pembelajaran kreatig yang dilakukan guru untuk meningkatkan belajar anak. Wawancara dilakukan kepada guru,dan setiap pertanyaan berkaitan dengan pembelajaran kreatif. 
Adapun upaya guru dalam kegiatan pembelajaran kreatif di masa pandemi covid 19 untuk meningkatkan belajar anak dapat kita lihat pada hasil wawancara berikut.

Guru: "Saya melakukan pembelajaran during dengan membuat whastaapp group kelas,dengan memberikan materi lewat ceramah yang saya buat video terlebih dahulu sebelum sya share ke group,sehingga anak akan melihat materi yang disampaikan guru,dan sebelumnya guru juga memberikan informasi dengan jelas tentang materi yang akan di perhatiakan.

Untuk melengkapi hasil observasi di atas maka akan dilengkapi dengan sumber informasi yang berupa hasil belajar anak.

Upaya guru dalam pembelajran kreatif di masa pandemic saat ini sangatlah penting. Dimana guru harus siap dengan perkembangan zaman saat ini dan diharapkan guru juga mampu mengikuti arus tekhnologi supaya tidak ketinggalan tatkala dunia pendidikan diuji dengan pembelajran jarak jauh.Sementara pembelajran harus tetap berjalan.Dengan kratif pembeajaran kreatif yang dilakukan guru tentunya mampu meningkatkan motivasi belajar anak.

Rendahnya motivasi belajar siswa dapat berdampak pada prestasi belajar siswa (Cleopatra, 2015). Motivasi belajar siswa satu dengan siswa yang lain berbeda, ada siswa yang memiliki motivasi belajar tinggi dan ada juga siswa yang memiliki motivasi belajar rendah.

\section{KESIMPULAN}

Kegiatan pembelajran during seharusnya dapat terlaksana secara sistematis sehingga dapat memberikan manfaat yang diinginkan. Melalui pembelajran during dengan menggunakan whastaapp group, tentunya anak akan lebih focus dalam belajarnya.Dengan metode ceramah yang disampaikan dengan membuat video sesuai dengan materi, setelah video sudah bagus siapdi share ke group.Anak di beri informasi tentang aturan dalam memperhatiakan materi yang akan disampaikan gru lewat video tersebut.

Adapun manfaat dengan model pembelajaran kreatif guru walaupun masih sangat sederhana yaitu dengan video pembelajaran, anak akan merasa dihadapan guru secara langsung. Oleh karena itu anak akan termotivasi sehingga bisa meningkatkan belajar anak di masa pandemic.

Wabah tersebut yang terjadi sekarang belum juga berakhir,sementara pembelajaran terhadap siswa harus bisa berjalan .Dalam hal ini guru di harapkan bisa menciptakan pembelajaran yang kreatif terhadap siswa sehingga bisa meningkatkan belajarnya.Dalam hal ini guru dituntut utk bisa memberikan pembelajaran dengan cara pembelajaran jarak jauh.Oleh karena itu guru harus mampu mengoperasiakan tekhnologi informasi walaupun dengan cara online lewat wasthaap.Guru mampu memberikan pembelajran yang kreatif dan menarik.Supaya dapat meningkatkan belajar siswa.

\section{DAFTAR PUSTAKA}

Cleopatra.M. 2015. Jurnal Ilmiah Pendidikan MIPA.5 (2)

Djam'an Satori dan Aan Komariah, Metodologi Penelitian Kualitatif (Bandung: Alfabeta, 2014), hlm. 149.

https://mediaindonesia.com/read/detail/25927 0-seluruh-pegiat-pendidikan-dimintabersiaphadapi-era-society-5.0

Jurnal Karya Ilmiah,Vol.5.No.1 Edisi.KBM Pandemi Covid-19

Jurnal Penelitian dan Kajian Sosial Keagamaan Vol. 17 No. 2. Juli-Desember 2020

Jurnal Stkipkusumanegara.ac.id.2020

Khamim Putro,"Pola Interaksi Anak dan Orang Tua selama kebijakan pembelajaran di rumah.

Nur.A.M (2020)Tugas Guru Sebagai Pengembang Kurikulum Ilmiah.DIDAKTIKA:Media

Ilmiah Pendidikan dan Pengajaran.12 (1). 59-67

Sugiyono. 2007. Memahami Penelitian Kualitatif. Bandung : Alfabeta

Sujarweni,Wiratna. 2014. Metodologi Penelitian. Yogyakarta: Pustaka Baru

Suprihatin, Jurnal Program Studi Pendidikan,Vol.3.No.1.2015

Syaharudin,S.\& Mutiani.M. 2020. STRATEGI PEMBELAJRAN IPS: Konsep dan Aplikasi. 